\title{
IRANIAN AND TURKISH FOOD CULTURES: A COMPARISON THROUGH THE QUALITATIVE RESEARCH METHOD IN TERMS OF PREPARATION, DISTRIBUTION AND CONSUMPTION
}

\author{
Gamze Gizem Avcıoğlu ${ }^{1}$ and Gürcan Şevket Avcıoğlu ${ }^{2}$ \\ ${ }^{1}$ Res. Asst., Selçuk University, Turkey, gizemertan28@hotmail.com \\ ${ }^{2}$ Dr., Selçuk University, Turkey, gsavcioglu@selcuk.edu.tr
}

\begin{abstract}
The purpose of this study is to make a comparative sociological analysis of Iranian and Turkish food cultures in terms of food preparation, distribution and consumption. Moreover, contribution is intended to be made to the field of applied food sociology. The research design carries features of a qualitative research. Of the qualitative research techniques, observation and interview form were used in the study. Research findings were obtained through observations made in Tehran, the capital city of Iran, and data were compiled by making interviews with people selected using the snowball sampling method. According to the results of observations and interviews, food habits in Iran tend to preserve their traditional characteristics. There are similarities rather than differences between Iran and Turkey in terms of eating habits and ways of eating. On the other hand, food culture is highly influenced by the food industry. Industrial food production, branding, packaging and wrapping are at an advanced level. Both Iran and Turkey are undergoing changes in terms of food as in other areas and coming under the influence of modernization. Food production, distribution and consumption systems or eating habits exhibit global trends. Although eating habits display global characteristics, they are always and in all communities based on local roots; in other words, the food culture is never separated from its cultural bonds.
\end{abstract}

Keywords: Eating habits, traditional way of eating, modern way of eating, eating at home, eating out, food industry.

\section{INTRODUCTION}

Nutrition is a basic need for human beings and can be understood as an individual condition in daily life. However, nutrition is a social phenomenon, not an individual one, because "while we eat, we do not only consume foodstuff; in fact, we also consume some senses and symbols" (Beardsworth and Keil, 2011, p. 90). Nutrition is not composed only of stuff consumed to survive; food also has symbolic meanings. Preparation, marketing and consumption of food involve certain attitudes as well as class and ethnic meaning differences (Lawson and Garrod, 2001, p. 94; Back, Bennett, Edles et al. 2012, p. 178). Therefore, one can talk about cultural dimension of food because "different cultures exhibit variation in terms of their approaches to food" (Giddens, 2000, p. 131). In this sense, the topic of food has become an issue in sociology, anthropology and sociology of culture (Back, Bennett, Edles et al. 2012, p. 178). Due to the increasing interest taken by sociology in the subject, food is evaluated within the framework of various social and cultural differences (Scott and Marshall, 2009, p. 259).

Individuals cannot obtain foodstuff required for them on their own. There is a need for various social organizations in the fields of production, distribution and consumption. These organizations begin in the 
family and extend so far as to include the state, because "preparation and consumption of food is intertwined with various other stages of social life" (Warde, 1997, p. 22). In the developmental process of societies, the stages of hunting and gathering, and farming and industry improved the cultivation of soil, processing of products and finally their consumption. Historically, developments in farming and industrialization profoundly altered nutritional habits and food cultures of societies. Today, nutritional habits are globalizing through modernization. Industrialization of nutrition and its tendency to globalize are transforming ways of production, distribution and consumption.

In this framework, observation of eating habits in Tehran, the capital city of Iran, their investigation using the qualitative research method and comparison with Turkish food culture constitute the subject matter of this study. This study is expected to contribute to cross-cultural comparative studies. Moreover, nutrition studies based on sociological grounds are relatively common in Western sociology. In Eastern societies, on the other hand, the number of sociological studies is few although food culture is well developed. Therefore, the present study is expected to contribute to the literature of sociology.

\section{SOME THEORETICAL APPROACHES TO RESEARCH ON FOOD CULTURE}

Nutrition and social relationships, social meaning of nutrition and changes in nutritional forms can be studied using various theories. For example, food and nutrition cultures of societies can be approached through structural, functional, conflict, modernization and exchange theories.

If food culture is viewed from a structuralist perspective, production, storage and consumption can be based on social history. In other words, any activity associated with nutrition results from the traditions or culture of the society and is not independent of all other activities of the society within the whole of the society. Food culture is part of social existence and social life.

Traditional ways of eating, what food will be eaten and food contents are determined on the basis of knowledge brought from the past. These traditional eating practices are supported by beliefs and maintain their legitimacy by being passed on from generation to generation. Rules and prohibitions of traditional menus are adopted by socialized individuals as they are and therefore regarded as natural and unchangeable. Violation of rules governing food can arouse feelings of bewilderment and disgust in individuals (Beardsworth and Keil, 2011, pp. 116-117). Claude Lévi-Strauss's studies are examples of the structuralist approach to food and it has become a useful tool in the investigation of cultural differences in prohibitions and orders connected with food in anthropological studies (Scott and Marshall, 2009, p. 259).

In the conflict approach, the job of producing, distributing and consuming food can be linked to social classes. It can be said that food production is the responsibility of a certain social class possessing means of production but at the same time there are conflicts among the classes regarding consumption. Ways of eating and drinking or habits vary in lower, middle and upper classes depending on expectations connected with socio-cultural environment, education and health. The common view is that the upper class consumes food containing high levels of protein as a result of their high economic income. Although the foodstuff that this class consumes contains high levels of protein, "it is light, delicious, hygienic and processed, but at the same time is consumed in amounts that will keep body size" (Beardsworth and Keil, 2011, p. 149). Apart from classical figures such as Marx, Weber and Simmel, many sociologists regard consumption as a matter of survival that results from uneven distribution of resources and a function of production. Consumption is a natural result of class positions and an expression of social hierarchy (Warde, 1997, p. 7). If food production and consumption are explained with reference to uneven distribution of food sources, then there are privileged classes that possess means of food production and those who have the sources benefit more from nutrition. This is a cause for conflict with other classes.

With modernization, significant changes have occurred in societies' ways of production, distribution and consumption. "With modernization, family firms, small-scale factories and small production facilities producing for limited and local markets in economy gave way to centralized, bureaucratized and large-scale markets" (Eisenstadt, 2014, p. 17). What made this structural change possible was that boundaries of areas of sales went far further than before. Initially, the producer and the merchant were combined in one person, but when they were separated from each other later, the merchant gained an unprecedented freedom of activity and relationships that could not be established before were established (Simmel, 2009, p. 234). These developments in production and distribution affected not only modernized societies but also modernizing societies. Patterns of marketing and consumption in pre-modern societies exhibited a tendency to resemble those in modern societies. For example, it is seen that in a Turkish village, the grocer has adopted modernity and attempts to place his environment within this modern life that he has envisioned. The store that the grocer dreams of running is an American super market in the full sense of the word where a 
variety of items abound and consumers have an option to choose from (Berger, Berger and Kellner, 1985, p. 156). Modernization turns understanding of consumption and the marketing business into integrated systems as the grocer in the Turkish village knows. In this way, consumers adopt a form of consumption in which various and abundant articles are available and can choose from among these.

There are some points where the modern nutrition system differs from the traditional system. For one thing, the modern nutrition system indicates a specialized sector; distribution of what has been manufactured takes place exclusively for commercial purposes; it points to variety and the opportunity to be able to choose from among these various products; it refers to globalization of markets (Beardsworth and Keil, 2011, pp. 60-61). Previous forms of food storage (conservation) tended to conserve the food's own natural state, whereas with industrialization, the chemical production of food improved (Whit, 1995, p. 47). It would be worthwhile to emphasize the very complex combination of technology, transportation facilities, industrialization, urbanization and international trade in the developments cited with regard to the modern nutrition system (Beardsworth and Keil, 2011, p. 63). George Ritzer (2013), discusses changes in this matter widely and conceptualizes as McDolandization of society. But he doesn't claim that traditional food habits are destroyed completely.

At the current state of affairs, food production is not a form of production where individuals or families meet their daily nutrition needs at home and meet their other needs by bartering their surplus food. The business of food production, distribution and consumption has been specialized, institutionalized and chemicalized.

\section{METHOD}

\subsection{The Subject and Purpose of the Study}

The subject matter of the study is to compare the food cultures (cuisines) of Iran and Turkey, which exhibit similarities and differences in terms of geography, history and culture. The purpose of the study is to determine the similarities and differences in traditional food preparation, distribution and consumption and at the same time to see to what extent nutritional habits in both societies are open to global-industrial influences. The observations and interviews with regard to this study were conducted in Tehran in August 2014.

\subsection{The Research Method and Data Collection Instruments}

This study was implemented using the qualitative research design. In the qualitative research design, standard techniques of quantitative studies are used less, the research design belongs to the researcher and, instead of following certain steps, interaction of research techniques is ensured (Maxwell, 2013, p. 3). The observation technique was used in this study. This observation was performed in Tehran, the capital city of Iran, occasionally accompanied by conversations with local people. However, a semi-structured interview form was used to reach findings that could not be obtained through observation. Literature about food was of great assistance in the preparation of the interview questions. The topics discussed in the relevant literature served as a source for the questions.

The interviews were held with 10 Iranian citizens composed of different ages, genders and professions, namely academics, civil servants and housewives. The interviewees were selected using the snowball sampling technique. The snowball sampling technique is one of the non-probability sampling techniques and sometimes considered to be a form of the random sampling technique. After interviews are held with a few people from the group, other people that will be recommended by them to give their ideas about the topic are reached (Babbie, 2014, p. 188). In this study, a group or an event was not investigated. However, since the population and the sample of the study could not be determined through other sampling techniques, interviews were held with a few people first and the other interviewees were chosen upon recommendation by the initial interviewees. The questions in the interview form were categorized in the data analysis stage as responses given to questions about food production, distribution and consumption. Responses given to questions under each title by different people were retold as they were by abbreviating the name and surname of the person responding. An interview was not held in Turkey; the knowledge and experiences of the researchers about the topic were deemed to be sufficient.

The problem statements serving as the foundation of the study were identified as follows:

1. How are food preparation, distribution and consumption implemented in Iran?

2. What are food habits like in Iran according to status? What are the similarities and differences compared with Turkey? 
3. What are the eating habits like outside the home?

4. What are the approaches of people and institutions like in terms of food safety and food control?

5. What is the effect of industrial food production and distribution on food habits in Iran and Turkey?

\subsection{Limitations of the Study}

Observations were made in various parts of Tehran for about a month to reach data concerning the research topic and eating and drinking behaviors were observed. The length of the observation can be considered insufficient in terms of obtaining detailed data about the topic. Apart from this, observations made indoors were limited. Therefore, predominantly forms of outdoor eating were evaluated. Shortcomings with regard to indoor eating were tried to be eliminated through the interview form. The use of snowball sampling method as the sampling technique can create problems in terms of representation of the population and generalization of the results. Therefore, information about the relevant literature, the observation technique and the snowball sampling method were used all together in order to increase reliability.

\section{FINDINGS}

\subsection{Observations in Tehran}

Some observations were made in central Tehran, Darband, Tajish, Farmanieh, Sa'adat Abad, Tehran Bazaar (Bazare Bozurg), Shahr-e Rey and Baharestan. There are restaurants in these areas where one can eat out and which have soups and stews on their menus. However, it cannot be said that such restaurants are high in number. On the other hand, fast food restaurants where pizzas, hamburgers or varieties of grilled meat can be consumed were more predominant. Apart from food, snack bar-like small-scale shops where one can consume fruit juice were encountered as frequently as fast food restaurants. In those bars, fruit juices like Abutalebi are freshly processed from seasonal fruit and served. Drinks are consumed fast and usually without sitting inside. It was found that people went to those places to chat or spend time.

It was observed that a large majority of the employees in both restaurants and snack bar-like places were male. Female employees were also encountered in a restaurant near Ferdowsi, in Darband and Farmanieh. There were female cashiers or employees in some restaurants.

Places where foodstuff was obtained were mostly district bazaars. It was observed that all kinds of foodstuff were available in the district bazaars in Tajrish and Imam Hossein neighborhood. Products such as meat, vegetables, fruit and nuts were sold both in pre-packed form and without packaging. In addition, some shopping centers in certain parts of the city, for example in Haft-e-Tir near Farmanieh, bore the qualities of a modern shopping center. The food hall in this shopping center was quite spacious and varied. Products were pre-packed and it was not different from other modern shopping centers in the world in that processed food was kept and displayed in fridges. However, it was observed that the prices there were higher compared with district bazaars. Therefore, it can be said that generally people with high incomes did their shopping in shopping centers.

Cooking was entirely undertaken by the lady of the house where we were invited as guests. Foodstuff can be kept in deep freezers after being processed. We were told that ingredients such as olive oil, tomato paste and spices were obtained from relatives living outside of Tehran.

Use of saffron in foods made both indoors and outdoors was widespread; for example, rice was always cooked with saffron and eaten with almost all meals. Cuce kebab, koobideh kebab and chelow kebab were common grilled foods in many outdoor places. Apart from them, widely consumed meals such as Ash-e Doogh, Abgusht and Ghormeh Sabzi were also encountered. In a small restaurant in Central Tehran, liver was cooked rare and served thus. When the cook was asked about this, he responded saying that it was the common cooking method. Many stalls were seen in Darband where various kinds of desserts were sold without packaging.

Apart from indispensable dishes, tea was consumed after all meals. Tea culture was quite advanced. It was hard to find Turkish coffee but one could easily reach good quality tea. It was observed that tea was consumed accompanied by a kind of sugar called nabat instead of putting sugar in the tea. The abundance of dessert varieties and high amounts of dessert production were worthy of attention. These desserts were sold in modern shops with beautiful decorations. 
Our overall observation about nutrition was as follows: as far as outdoor eating habits were concerned, fast food, grilled meat and rice cooked with saffron were widely consumed; pre-packed and processed food were heavily used; food safety and sanitary conditions were paid attention to; local specialties dominated; there was branding in the production of foodstuff and that food industry was well developed.

\subsection{Analysis of the Interview Form}

Due to the research design, data analysis was not conducted statistically. Only, the responses given to the questions were interpreted.

\subsection{Findings about Food Preparation}

There is a functional difference between urban and rural areas in the obtainment of food. Wheat and rice are two important components of Iranian food culture. Especially, extremely widespread use of rice can be considered amazing. In an environment like Iran where dry climate usually prevails, existence of a foodstuff that is found in wetlands can arouse curiosity as to where rice comes from. The area that is appropriate for cultivation of rice involves Iran's coasts around the Caspian Sea and rice spreads there from all parts of the country (Daniel and Mahdi, 2006, pp. 151-152; Nesbitt, Simpson and Svanberg, 2010, p. 322). Foodstuff other than rice is obtained both from close surroundings of Tehran and other parts of Iran.

How are food components used in food obtained in Tehran?

Ali Ş.: Tomatoes come from Shiraz whereas Talebi comes from Semnan as well as from villages of Tehran; they are packaged in Tehran; imports are limited.

Ismail T.: It comes from Tehran and its surroundings.

Marjan F.: Usually, meat and wheat come from outside, that is, they are imported. They usually come from surrounding areas.

Younes A.: Things like fruit are limited in Tehran; they usually come from villages and other cities. Fruit and vegetables abound in places where water also abounds.

It is understood from the responses that foodstuff is usually obtained from rural areas outside Tehran. A similar situation is also valid for Turkey. As in Tehran, metropolitan cities are places where raw materials of food are hard to find on site. However, since Turkey is more suitable for farming due to climatic conditions, it is easier to obtain food from rural areas close to large cities.

What are the cooking methods? Is food preferred to be well-done or rare?

Ali Ş.: It depends on the food.

Homeyra M.: It depends on personal taste. Some people like their food well-done whereas others like rare.

Soheila M.: We do not cook vegetables for long but we do not want chicken and red meat to be raw.

It can be understood from the responses given that there is not a specific form of cooking. The food's being rare or well-done can be considered to be a personal preference. However, our observations were that especially grilled food is cooked well-done. In Turkey, too, the preferred form of cooking is usually well-done. Contrary to some cultures, the habit of eating food raw or almost raw is almost next to nothing.

How often dried food is used?

Ali Ş.: Very little in Tehran.

Behrouz B.: It has increased.

Soheila M.: Dried food is available in Tehran but there is not much. It is produced more in villages.

Deep freezers are predominantly used to store foodstuff for long periods for later use. Drying and salting are traditional ways of storing and using food for long periods. This form of production and storage is also frequently observed among housewives in Turkey and it contributes significantly to home economics.

Meals can be regarded as a fundamental symbol of social differentiations based on class, age, gender and ethnicity (Beardsworth and Keil, 2011, p. 92). Meals have a significant place in the Turkish tradition. Meals are considered to be of paramount importance in almost all stages of social life and in most of the social interactions. Meals are eaten together at birth, circumcision and funeral ceremonies and joys and sorrows are shared (Eröz, 1977, pp. 158-159). Likewise, in Iran, meals constitute a tradition that reinforces social relationships, strengthens social connections and improves solidarity at home and among relatives and 
friends as well as assemblies and societies. A proverb says one way of winning one's honor is to share your meal with him (Daniel and Mahdi, 2006, p. 150). Therefore, much attention is paid to collective meals in both cultures. Such meals are important not only for maintaining social relations but also for sustaining differentiation in status outside the family.

Are special dishes cooked for guests on special days?

Ali Ş.: Guests are held in high esteem. Special food is prepared for them. The best of everything is prepared.

Homeyra M.: Guests are really held in high respect. By all means, special dishes are cooked. Even if the host or hostess does not have enough money, they cook different kind of dishes.

Younes A.: Dishes harder to make are cooked. Ample food is cooked for crowded guests.

The business of preparing such meals is an indication of status in both cultures. It points to the status of either the guest or the person who prepares and offers the meal. In fact, this sometimes becomes an overly ostentatious event. In both cultures, preparing food for guests can be regarded as a practice similar to "potluck".

\subsection{Findings about Distribution and Marketing of Food}

\subsubsection{Control of Food Distribution}

The part played by governments is again important in organizing the food industry, distributing food evenly to the society at large and determining and standardizing food quality because quantitative inadequacy of food or low quality food may lead to social problems. Governments prepare social programs to this end (Sobal and Maurer, 1995, pp. 2-8). Apart from social programs, "governments may prevent food imports on the grounds that that food supply from abroad will weaken the country politically" (McIntosh, 1996, p 54). In Iran and Turkey, food control is an important process but does not work properly.

Are the food items halal, safe and under guarantee in terms of hygiene and controlled by the government?

Ali Ş.: There is strict state control. Disobedient shops are closed, and fines are huge.

Homeyra M.: I cannot say that they are controlled properly. Diseases have increased sharply in Iran in recent years, because of foods.

Mahdi H.: They are not controlled much.

Marjan F.: All of them are halal.

As in all societies, food control is also important for consumers in Iran. Naturally, the state is expected to fulfill this control. However, consumers do not seem to be sure that sufficient control is being exerted. The same also holds true for Turkey.

Are the safety and hygiene of foods questioned by consumers and to what extent do consumers pay attention to this?

Behrouz B.: They question very little; since the middle class is overwhelming in number, they do not question as much as the rich.

Soheila M.: Meticulous people who care about their health question, examine and usually check expiry dates of foods. If foods are sold without packaging, it is impossible to know.

Younes A.: Consumers pay attention to this; expiry dates are checked.

Food safety is ensured by states or local authorities but consumers also have a role to play in this regard. When consumers perform their own control on food items, this indicates informed consumption. It is understood that in general, consumers in Iran are inquisitive about food safety and hygiene. However, those who think that the state has a strict control over food items may say that they do not bother to question. Questioning of the safety and hygiene of food items in Turkey is increasing in parallel with rising awareness in this respect. Nevertheless, the extent of questioning varies by level of education, level of income and class status.

\subsubsection{Ways of Marketing}

One of the important features of the modern food sector concerns wrapping and packaging. Both packaged and unpackaged food items can be seen to be sold in market places of countries like Turkey and Iran where traditional methods of production, distribution and consumption go hand in hand with modern methods. 
How is the marketing system in Iran? Do district bazaars or supermarkets dominate?

Ahmad T.: Food items are predominantly bought at bazaars.

Ismail T.: The rich buy at supermarkets while the poor at bazaars.

Marjan F.: Foods are bought at both but if the bazaar is big, then they are bought at the bazaar. People go less to the bazaar due to heavy traffic.

In Iran, both district bazaars and supermarkets meet people's need for food. It is understood from the responses that class differences based on level of income determine whether district bazaars or supermarkets will be preferred. In Turkey, too, district bazaars are places which lower and middle class people predominantly prefer. Moreover, lifestyles and expectations of prestige may be a determining factor in preferring the supermarket.

What is the situation of branding and packaging in food items?

Behrouz B.: It is only just beginning but has not turned into a culture yet. Packaging is not preferred due to its cost. After all, packaging is not safe.

Mahdi $\mathrm{H}$.: Packaging and branding are limited.

Younes A.: There has to be a brand or owners are fined. There are civil servants for this task.

It was seen that packaging and wrapping is common in district bazaars in Iran. Packaging and wrapping is almost nonexistent in district bazaars in Turkey. Branding is increasing in both cultures. More and more food producers are offering their products to consumers with their own brands.

Do people bargain when they go shopping in bazaars and supermarkets?

Ali Ş.: You cannot bargain; municipal officers supervise the bazaar.

Behrouz B.: Yes, they do, but not in markets and municipal bazaars.

Younes A.: Bargaining occurs, indeed, Iranian people like bargaining. They ask the seller to reduce the price from 100 tumen to 10-20 tumen (Iranian currency).

An important point in terms of food safety and consumer rights is standardization in prices. The state seems to have ensured this standard in Iran. Prices are printed on all products that are wrapped or packaged and they are sold at these prices. Products of the same kind and quality are also made to be sold at one single price in district bazaars. However, it can be said that people bargain for certain products under certain conditions. The situation is a little different in Turkey. It is seen that price standardization has been ensured in certain products. However, bargaining and price differences are more common. It is possible to say that economic policies of the countries play a part in this. Free market economy is implemented more effectively in Turkey.

What is the level of incorporation in the production of industrial food?

Ali Ş.: There are many corporations.

Masoumeh K.: There are many corporations in Tehran.

Mahdi: There are many more corporations

In modern food industry, organizations offering food services generally do not produce their food items. There are intermediary organizations or companies between food production and marketing. They are functional components of the food industry. It is seen that incorporation is widespread in Iran.

\subsection{Findings about Food Consumption}

Traditional ways of eating have been replaced by rational ways of eating as a result of social change. What is meant by the rational way of eating may involve issues such as losing or gaining weight, developing physically and mentally, protecting the self from certain diseases and keeping one's health. Such ways of eating are usually based on scientific or quasi-scientific principles as well as certain measurements and calculations. We can also make mention of fixed (convenience) menus, which are closely affiliated with rational menus. The main goal in these menus is to reduce to minimum the time and effort needed to prepare and serve the food (Beardsworth and Keil, 2011, p. 117). 


\subsubsection{Ways of Consumption}

What is the rate of consumption of solid and liquid foods at home in Iran? What are the rates of soup, meat and vegetable consumption?

Ahmad T.: There are at least ten soup varieties and soup is consumed a lot.

Behrouz B.: Home-made foods are mostly composed of slops.

Homeyra M.: We do not eat kebab-like meals at home. We eat foods made from vegetables.

Masoumeh K.: We do not cook dishes without meat; we definitely use meat in all our foods.

It was observed that the food that was eaten out usually involved solid dishes such as grilled food. It can be said that the dishes cooked at home often contained vegetables but of course with the addition of meat. In addition, it is possible to say that soup consumption is also very high, because "soup is a staple diet of Iranian cuisine, there are many varieties of soup. Each is named after the most essential ingredient in it. For example, one of the most common soups is 'ash-reshteh', which is made from broad beans or black eyed beans, vegetables or home-made fettuccini" (Daniel and Mahdi, 2006, p. 154). Meat consumption is also high in Turkey. However, level of income plays a significant part in this. Meat consumption is quite limited in classes with a low income level. In other words, it is not possible to add meat to all their meals. Soup varieties are also rich in Turkey and soup is consumed extensively.

What are the foods that are not eaten or forbidden to eat?

Ali Ş.: Nothing except alcohol and pork.

Soheila M.: Some foods are prohibited by the religion. All is eaten except for the forbidden ones.

Marjan F.: Pork.

The role of religious belief is important in food items that are not preferred or forbidden. Alcohol and pork are not consumed in Iran as they are forbidden. In Turkey, too, pork and alcohol are not much preferred due to religious beliefs but they are not prohibited by law. One can see people consuming alcohol together with meals.

Is there a seating arrangement for the family at meal tables?

Ahmad T.: Yes, it is important and everyone has a pre-assigned place.

Behrouz B.: There is not an absolute rule but still there is some in a way. The guest of honor also exists in Turkey. Wherever the back pillow is, the father sits there. The grandfather's place is specified. Floor table is common; the table is a new thing.

Marjan F.: Yes, everyone's place is assigned.

Younes A.: The elderly sit aloof. The father does not sit at the entrance; like giving your seat to the elderly on the bus.

The order of seating during a meal can be added to the differences in eating behaviors within the family and among classes. Social status determines the order of seating. For example, according to Turkish traditions, there is a seating arrangement at the table determined on the basis of the position of the family members in the family. Likewise, the place at the table where a guest invited to a meal is made to sit is called "tör"; differences in status are indicated by sitting on the right and left of the guest who sits at the center of the table (Beşirli 2012, 118). In a meal where only family members are present, the father of the family or the eldest member sits at the center of the table. If there is a guest, they are placed at the center. "Table manners and having guests, which show status, are important for Iranians, too, and these ancient traditions in Iran date back to rituals in Zoroastrianism and Islam" (Hadi, Keberi 2011, 119).

\subsubsection{Food Consumption outside the Home}

The roots of the habit of eating out can be dated back to very old times in Iran. Eating out had become a habit from the period of Zoroastrianism to the Safevids and the Kajars in the cities of Isfahan, Tabriz, Shiraz, Tehran and southern cities of Iran. Today, this custom is maintained in the form of eating out every day. Businessmen in particular eat breakfasts and lunches at restaurants (Iktisad ve Namayeshgah, 2015, pp. 1011, http: // www. ecobition. Ir / Modules / News / PrintVer. Aspx? News _ ld = 2022 \& V _ News _ ld = \&Src $=$ Main). 
Iran's cuisine may vie with other rich cuisines of the world with its own style and peculiar characteristics but it is not as famous. Apart from being shaped by authentic ingredients, Iranian dishes have been influenced by Indian, Turkish, Central Asian and Middle Eastern cuisines. Moreover, recent immigration from other countries to Iran, especially from Europe and the USA, has significantly changed the appearance of Iranian restaurants so that they now look like the ones in those countries (Daniel and Mahdi, 2006, p. 149). The same situation is also true for Turkey. Eating out has meanings beyond just filling one's stomach. The smart and hygienic appearance and quality of service of a place make it preferable for eating out.

Is the culture of eating out common? Does eating out vary by income groups?

Ali Ş.: People generally eat at home, but the rich usually eat out.

Behrouz B.: People eat out once a week, which is an influence from the European culture. This is more common in the summer and is increasing day by day.

Ismail T.: People usually eat at home. If they have a lot of money, they can also eat out. But, generally, they eat at home.

Eating out is not a common way of consumption implemented within the family in either Iran or Turkey. As can be understood from the responses, eating at home is predominantly preferred over eating out. It can be said that there are significant differences in terms of the frequency of eating out and restaurants where eating out takes place.

Is eating out a necessity, a luxury or a pleasure?

Behrouz B.: Eating out with the family is a pleasure. When one is out for business, people naturally eat out.

Younes A.: Eating out is for pleasure. However, the old do not like eating out; the young do more.

As is understood, the behavior of eating out results from a desire to break with the routine of eating at home. Eating out is part of the time spent at shopping centers or bazaars. At the same time, families turn it into a pleasure. The situation is similar both in Iran and Turkey.

\section{CONCLUSION}

According to the findings obtained from the observations and interviews, food items are obtained from within the country in both Iran and Turkey. There are imported products but they do not constitute a considerable amount. It can be understood from this that there is no dependence on other countries in regard to food production.

There are differences among social classes in terms of carbohydrate, protein and vitamin consumption. There is an overall tendency to eat at home. Yet, eating out is common due to working conditions or for pleasure and fun.

Food safety and control is important but insufficient in both countries. Although the attention of both public institutions and consumers focuses on this issue, the desired level of safety and control cannot be provided.

Incorporation and marketing of the products after packaging are common in the food industry in both countries, which means that the food industry is quite developed.

The food culture in Iran is under the influence of modernity and Western way of nutrition. Rapidly spreading fast food shops are an indication of this. All the same, the sauces, cheese and other ingredients used in the dishes cooked in those shops, pizzas for example, are of Iranian origin and closer to Iranian taste (Daniel and Mahdi 2006, p. 150). As this statement indicates, food production, distribution and consumption systems or eating habits exhibit global trends. Although eating habits display global characteristics, they are always and in all communities based on local roots; in other words, the food culture is never separated from its cultural bonds.

\section{REFERENCE LIST}

Babbie, E. (2014). The Practice of Social Research (14th Edition). Boston: Cengage Learning.

Back. L., Bennett, A., Edles, Laura D. et al. (2012). Cultural Sociology: An Introduction. West Sussex: WileyBlackwell.

Beardsworth, A. and Keil, T. (2011). Yemek Sosyolojisi, Yemek ve Toplum Çalışmalarına Bir Davet. Ankara: Phoenix Yayınevi. 
Berger, Peter L., Berger, B. and Kellner, H. (1985). Modernleşme ve Bilinç. İstanbul: Pınar Yayınları.

Beşirli, H. (2012). Yemek Sosyolojisi Yiyeceklere ve Mutfağa Sosyolojik Bakış. Ankara: Phoenix Yayınevi.

Daniel, Elton L. and Mahdi, Ali A. (2006). Culture and Customs of Iran. London: Greenwood Press.

Eröz, M. (1977). Türk Kültürü Araştırmaları. İstanbul: Kutluğ Yayınları.

Eisenstadt, Shmuel N. (2014). Modernleşme. Ankara: Doğu-Batı Yayınları.

Giddens, A. (2000). Sosyoloji. Ankara: Ayraç Yayınevi.

Hadî, V. and Keberî, N. (2011). "Adab-e sofre der Iran-e bastan ve Iran-e dovre-ye Islamî-ye gharn-e dovvom ta heftom hicrî". Meshkatedu, Paeez, Shomare: 112, pp. 119-137.

Iktisad ve Namayeshgah. (2015). "Berresî-e adab ve ferheng-e ghaza khorden-e Iraniyan der dovreha-ye mokhtalef-e tarikhî khordad", 2014 Shomare 55, pp. 10-11. http://www.ecobition.ir /Modules/News / PrintVer.aspx? News_ld = $2022 \& V_{-}$News_ld $=$\& Src = Main

Lawson, T. and Garrod, J. (2001). Dictionary of Sociology. Chicago: Fitzroy Dearborn Publishers.

Maxwell, Joseph A. (2013). Qualitative Research Design: An Interactive Approach. Thousand Oaks CA: Sage Publications.

Mclntosh, W. A. (1996). Sociologies of Food and Nutrition. New York: Plenum Press.

Nesbitt, M. Simpson, John St. and Svanberg, I. (2010). "History of Rice in Western and Central Asia". In S. D. Sharma (eds.). Rice Origin Antiquity and History, pp. 312-344. New York: Science Publishers.

Ritzer, G. (2013). The McDonaldization of Society. Washington DC: Sage Publication Ltd.

Scott, J. and Marshall, G. (2009). Dictionary of Sociology. New York: Oxford University Press.

Simmel, G. (2009). Bireysellik ve Kültür. İstanbul: Metis Yayınları.

Sobal, J. and Maurer, D. (1995). "Food, Eating and Nutrition as Social Problems". In D. Maurer and J. Sobal (eds). Eating Agendas: Food and Nutrition as Social Problems. pp. 2-8 New York: Aldine de Gruyter.

Warde, A. (1997). Consumption Food and Taste. London: Sage Publications Ltd.

Whit, William C. (1995). Food and Society A Sociological Approach. New York: General Hall Inc. 